\title{
Karakteristik Darah Mimi (Tachypleus gigas) sebagai Pendeteksi Bakteri Kontaminan Penghasil Endotoksin Pada Produk Perikanan
}

\author{
Romadhon*, Selamet Suharto, Sumardianto \\ Program Studi Teknologi Hasil Perikanan, Fakultas Perikanan dan Ilmu Kelautan, Universitas Diponegoro \\ Jl. Prof. Sudarto, SH, Tembalang, Semarang, Jawa Tengah, 50275 \\ Email: romi_thp@yahoo.co.id
}

\begin{abstract}
Abstrak
Kepiting tapal kuda atau mimi lan mintuno atau belangkas (suku Limulidae) mencakup empat jenis hewan beruas (Artropoda) yang menghuni perairan dangkal wilayah payau dan kawasan mangrove. Mimi merupakan salah satu sumberdaya genetika yang dilindungi. Mimi juga memiliki karakteristik tersendiri dalam darahnya. Umumnya hewan darat maupun laut memiliki darah berwarna merah. Namun, darah pada mimi berwarna biru. Pada (Tachypleus gigas) memiliki ekstrak darah kemungkinan mengandung senyawa antibakteri. Tujuan memisahkan dan mengkarakterisasi darah limulus dan menskrining hasil pemisahan darah dengan bakteri patogen. Hasil Penelitian 10 ekor mimi yaitu 165,72 ml. Setelah disentrifuse dihasilkan supernatan 90,633 ml dan 23,304 pelet. Hasil analisis fitokimia banyak dihasilkan pada supernatan terutama alkaloid, fenol, tannin, alkaloid. Berdasarkan skrining dengan bakteri patogen tidak dihasilkan zona hambat karena pengenceran terlalu kecil.
\end{abstract}

Kata Kunci : Darah mimi, Bakteri Patogen, Fitokimia.

\section{Abstract \\ Characteristics of Blood Mimi (Tachypleus gigas) as Detecting Bacteria Contaminant Producing Endotoxin In Fishery Products}

Horseshoe crab or mimi lan mintuno or trim (Limulidae tribe) includes four types of extending animals (Artropoda) that inhabit the shallow waters of the brackish area and the mangrove area. Mimi is one of the protected genetic resources. Mimi also has its own characteristics in the blood. Generally land and sea animals have red blood. However, the blood on the mimi is blue. In (Tachypleus gigas) has Limulus Amebosit Lysate blood extract (LAL). The purpose of separating and characterizing blood limulus and screening the results of blood separation with pathogenic bacteria. Research result of 10 tail Limulus sp that is 165,72 ml. After centrifugation, the supernatant produced 90,633 $\mathrm{ml}$ and 23,304 pellets. The result of phytochemical analysis is mostly produced on supernatant especially alkaloid, phenol, tannin, alkaloid. Screening with pathogenic bacteria does not result in inhibit zone because dilution is too small.

Keywords: Mimi blood, Pathogen Bacteria, Phytochemistry

\section{PENDAHULUAN}

Kepiting tapal kuda atau mimi lan mintuno atau belangkas (suku Limulidae) mencakup empat jenis hewan beruas (artropoda) yang menghuni perairan dangkal wilayah payau dan kawasan mangrove. (Monica, et.al., 2016). Penelitian tantang karakter mimi (Tachypleus gigas) sudah dilakukan. Tachypleus gigas biasanya berukuran lebih besar dan ekor berbentuk segitiga dalam potongan melintang LON-LIPI (1973). Karakterisasi morfologi dan identifikasi molekuler dengan marka gen Co1 pada mimi (Tachypleus gigas) di Utara Pulau Jawa. (Meilana et al, 2016)
Mimi atau blangkas merupakan salah satu sumberdaya genetika yang dilindungi sesuai dengan SK Menteri Kehutanan No. 12/KptsII/1987 dan Peraturan Pemerintah RI No. 7/1999 (Rubiyanto, 2012).

Kepiting tapal kuda tidak memiliki hemoglobin dalam darah mereka, tapi menggunakan hemocyanin untuk membawa oksigen Karena mengandung tembaga terdapat dalam hemosianin sehingga darah mereka berwarna biru. Darah mengandung amebosit, yang memainkan peran serupa ke sel darah putih vertebrata dalam mempertahankan organisme 
melawan patogen. Amebosit dari Darah L. polyphemus digunakan untuk membuat Limulus amebocyte lysate (LAL), yang digunakan untuk deteksi endotoksin bakteri dalam pengobatan Di negara maju seperti Amerika, Jepang, dan Eropa mereka memanfaatkan darah mimi untuk digunakan sebagai pendeteksi alat-alat kedokteran agar bebas dari bakteri dan jamur. Darah mimi juga dapat digunakan sebagai LAL (Limulus Amoebocyte Lysate) test. (Funkhouser, 2011)

Kepiting tapal kuda dewasa dikumpulkan pada kapal pukat atau dengan panen tangan dan diangkut ke lab sebuah perusahaan biomedis kemudian dicuci dan ditempatkan di rak. Kepiting tapal kuda diambil darahnya dari pericardium dengan jarum sekitar 30\% dari Darah binatang diangkat. Dalam waktu 72 jam, Kepiting tapal kuda berdarah dikembalikan ke tempat penangkapan dan melepaskan hidup (Leschen dan Correia, 2010)

Mimi telah banyak dimanfaatkan dalam bidang farmasi maupun sebagai sumber makanan. Pada Limulus polyphemus memiliki ekstrak darah Limulus Amoebocyte Lysate (LAL), Tachypleus sp. menghasilkan Tachyplesin Amoebocyt Lysat (TAL) dan Carcinoscorpius rotundicau menghasilkan Carcinoscorpius Amoebocyt Lysat (CAL), dapat mendeteksi endotoksin bakteri gram negatif, endotoksin darah manusia, dan patogen pada produk obat-obatan. Industri farmasi LAL dimanfaatkan untuk mensterilkan antibiotik (Bhonde et al, 2002).

Endotoksin bakteri gram negatif dikenal dengan nama lipopolysaccharide (LPS) sebagian besar dihasilkan oleh bakteri gram negatif pada dinding sel terluar. LPS ini dapat dikeluarkan setelah merusak dinding sel bakteri. Endotoksin dapat berinteraksi dengan reseptor yang spesifik padasistem kekebalan sel dan menginduksi ekspresi dalam jangkauan yang luas pada sistem pertahanaan termasuk inflamantory cytokines, nitric oxide, eicosanoids. Tujuan penelitian ini yaitu mengektraksi dan mengkarakterisasi darah mimi, dan menskrining dengan bakteri patogen.

\section{MATERI DAN METODE}

Mimi (Tachypleus gigas) yang diambil darahnya diperoleh dari Desa Pecangakan, Kecamatan Batangan, Kabupaten Pati. Bahan kimia yang digunakan $50 \mathrm{mM}$ NaAcetate, EDTA, $5 \mathrm{mM}$ PMSF, $1 \mathrm{mM}$ pepstatin, iodoacetamide, $\mathrm{pH} 4.5 \mathrm{CaCO}_{3}, \mathrm{Na}$ azide, $\mathrm{B}$ (oxoid), $1 \mathrm{~N} \mathrm{NaOH}, 1 \mathrm{~N} \mathrm{HCL}$. with 0.5\% Tris buffered saline (TTBS) [20 mM Tris,
$\mathrm{NaCl}, 0.05 \%$ Tween-20, 5\% non-fat dried milk in TTBS for 1 .

Alat-alat yang akan digunakan dalam penelitian ini adalah autoclaf (All America), timbangan analitik (Libror AEG -220), bio freezer $-80{ }^{\circ} \mathrm{C}$ (Forma Scientific), incubator $37^{\circ} \mathrm{C}$ (Leec), oven (Memmert), mikropipet (Eppendorf), stirrer plate (nuova II), mikroskop fase kontras (Nikon), mikrosentrifuse (Beckman Microfuge 11), $\mathrm{pH}$ meter 691 (Metrohm), HPC, SDS PAGE elektroforesis.

\section{Pengambilan Darah Mimi}

Pengambilan darah mimi (Tachypleus gigas) dengan cara melipatkan bagian prosoma ke dalam. Masukkan jarum suntik di bagian otot yang menyekat di antara prosoma dan ophistosoma. Kemudian darah disimpan dalam botol sampel dan disimpan dalam kondisi dingin atau kotak bersinsulasi. Darah yang diambil $100 \mathrm{~mL}$. Setelah diambil darahnya mimi bisa langsung dilepaskan.

\section{Pemisahan Darah mimi}

Pemisahan darah dilakukan menurut metode dari (Mac Person $F$,1996). Setelah darah diperoleh kemudian di sentrifuse dengan kecepatan 15.000 rpm selama 30 menit. Kemudian darah dipisahkan antara pelet dan supernatan kemudian dikarakterisasi senyawa antibakterinya.

\section{Uji Kadar Fenol Metode Folin-Ciocalteu} (Hardiana et al., 2012)

Pembuatan reagen asam galat $50 \mathrm{mg} / \mathrm{l}$. Sebanyak $0,05 \mathrm{~g}$ asam galat ditambahkan $5 \mathrm{ml}$ etanol $95 \%$ dan aquadest sampai volume menjadi $50 \mathrm{ml}$. Selanjutnya diambil $2,5 \mathrm{ml}$ dan diencerkan sampai $50 \mathrm{ml}$ menggunakan aquadest.

\section{Uji Kadar fenol}

Sebanyak $1 \mathrm{mg}$ ekstrak ditambahkan $1 \mathrm{ml}$ etanol 95\%, lalu divortex. Setelah itu, diambil 0,1 $\mathrm{ml}$ larutan ekstrak tersebut dan ditambahkan 0,1 ml reagen Follin-Ciocalteu 50\%, selanjutnya divortex lagi dan ditambahkan $2 \mathrm{ml} \mathrm{Na} 2 \mathrm{CO} 32 \%$ lalu divortex kembali. Selanjutnya campuran tersebut diinkubasi selama 30 menit. Absorbansi sampel dibaca dengan panjang gelombang $750 \mathrm{~nm}$. Kandungan total fenolik dari ekstrak dihitung dengan menggunakan kurva standar asam galat.

Uji Total Flavonoid (Rohaeti et al., 2011)

Ekstrak kental $200 \mathrm{~mL}$ dimasukkan ke labu bulat. Sistem hidrolisis yang digunakakan yaitu $1 \mathrm{ml}$ larutan heksametilentetramina $0,5 \% \mathrm{~b} / \mathrm{v}$, $20 \mathrm{ml}$ aseton, dan $2 \mathrm{ml} \mathrm{HCl} \mathrm{25 \%} \mathrm{ditambahkan} \mathrm{ke}$ dalamnya. Selanjutnya, ekstrak dihidrolisis dengan 
pemanasan hingga mendidih selama 30 menit. Campuran hasil hidrolisis disaring dengan kapas ke dalam labu ukur $100 \mathrm{ml}$. Residunya kemudian ditambahkan $20 \mathrm{ml}$ aseton dan didihkan kembali lalu ditera. Sebanyak $20 \mathrm{ml}$ filtrat hasil hidrolisis dan $20 \mathrm{ml}$

\section{Analisis kadar protein}

Uji kadar protein menggunakan metode Mikro-Kjeldhal (AOAC 2005). Sampel kering sebanyak 5gram ditempatkan dalam labu Kjeldahl $100 \mathrm{~mL}$ dan ditambahkan 0,25gram selenium dan 3 $\mathrm{mL} \mathrm{H}_{2} \mathrm{SO}_{4}$ pekat, selanjutnya dilakukan destruksi (pemanasan dalam keadaan mendidih) selama 1 jam sampai larutan jernih. Setelah dingin ditambahkan $50 \mathrm{~mL}$ akuades dan $20 \mathrm{~mL} \mathrm{NaOH}$ 40\% lalu didestilasi. Hasil destilasi ditampung dalam labu Erlenmeyer yang berisi campuran 10 $\mathrm{mL} \mathrm{H}_{3} \mathrm{BO}_{3} 2 \%$ dan 2 tetes indikator Brom Cresol Green-Methyl Red berwarna merah muda. Setelah volume hasil tampungan (destilat) menjadi $10 \mathrm{~mL}$ dan berwarna hijau kebiruan, destilasi dihentikan, kemudian destilat dititrasi dengan $\mathrm{HCl} 0,1 \mathrm{~N}$ sampai berwarna merah muda. Perlakuan yang sama dilakukan juga terhadap blanko.

\section{Kadar Lemak (AOAC, 2005)}

Sample 1-2gram dibungkus dengan kertas saring. Kemudian dikeringkan dalam oven bersuhu $105^{\circ} \mathrm{C}$ hingga kering. Setelah itu kertas saring dimasukkan kedalam selongsong dan ditahan dengan kapas. Selongsong tersebut kemudian dimasukan ke dalam alat ekstraksi soxhlet dan dihubungkan dengan kondensor dan labu lemak. Pelarut hexana dimasukan ke dalam labu lemak secukupnya. dan dilakukan ekstraksi selama 6 jam. Pelarut yang ada dalam labu lemak didestilasi dan ditampung kembali. Kemudian labu lemak yang berisi lemak hasil ekstraksi dikeringkan dalam oven pada suhu $105^{\circ} \mathrm{C}$, didinginkan dalam desikator dan ditimbang. Pengeringan diulangi hingga mencapai berat tetap. Kadar lemak dapat diperoleh dengan persamaan berikut :

Kadar lemak

Kadar Lemak

$$
(\% \mathrm{wb})=\frac{\text { Berat Lemak }}{\text { Berat Sampel }} \times 100 \%
$$

$$
(\% \mathrm{db})=\frac{\text { Kadar Lemak }(\% \mathrm{wb})}{100-\text { Kadar Air }(\%)} \times 100 \%
$$

\section{Rancangan Percobaan}

Rancangan percobaan yang digunakan dalam penelitian ini adalah Rancangan Acak Lengkap (RAL) yang terdiri dari 1 macam faktor yaitu Darah, supernatan, dan pellet mimi dengan ulangan sebanyak tiga kali. Pengujian normalitas dan homogenitas dilakukan terlebih dahulu sebelum analisa ANOVA, agar dapat diketahui sifat data sehingga dapat dilakukan sidik ragam atau tidak. Metode analisa yang digunakan adalah sidik ragam ANOVA dengan uji lanjut untuk menentukan nilai yang berpengaruh maupun yang tidak dengan Uji BNJ (Beda Nyata Jujur).

\section{HASIL DAN PEMBAHASAN}

\section{Ekstrak darah mimi}

Pada proses isolasi darah mimi dapat dihasilkan rata-rata $15-16 \mathrm{ml}$ darah per ekor. Darah ini diambil dibagian belakag dekat kerapas bagian depan. Pengambilan darah dilakukan dengan syringe dan dimasukan ke otol sampel. Dari sepuluh ekor limulus dihasilkan darah sekitar 165,72 ml. Setelah dilakukan sentrifuse dihasilkan supernatant 90,633 $\mathrm{ml}$ dan 23,304 pelet. Sentrifuse yang dilakukan dengan kecepatan $7000 \mathrm{rpm}$.

\section{Kadar Protein}

Berdasarkan uji statistik diperoleh hasil adanya perbedaan nyata $(\mathrm{P}<0,05)$.Hasil analisa kadar protein pada Tabel 1 menjelaskan bahwa sampel darah memiliki kandungan protein $5,32 \pm 0,05$, sedangkan sampel supernatan mempunyai kandungan protein sebesar $6,81 \pm 0,07$, dan sampel pellet mempunyai kandungan protein

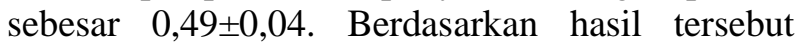
kandungan protein yang paling banyak terdapat supernatant. Hal ini disebabkan karena protein banyak yang terlarut disupernatan dan tidakmengendap bersama pelet. Protein larut bersama cairan dalam suoernatan.

Tabel 1. Kadar Protein pada sampel

\begin{tabular}{llr}
\hline No & Keterangan & Rata-rata \\
\hline 1. & Sampel Darah & $5,32 \pm 0,05^{\mathrm{a}}$ \\
2. & Sampel Supernatan & $6,81 \pm 0,07^{\mathrm{b}}$ \\
3. & Sampel Pellet & $0,49 \pm 0,04^{\mathrm{c}}$ \\
\hline
\end{tabular}

Keterangan :

- Nilai pada tabel merupakan hasil rata-rata dari tiga ulangan

- Data yang diikuti tanda huruf kecil yang berbeda pada bagian atasnya menunjukkan adanya perbedaan nyata $(\mathrm{P}<0,05)$

\section{Kadar Lemak}

Berdasarkan uji statistik diperoleh hasil adanya perbedaan nyata $(\mathrm{P}<0,05)$.Hasil analisa kadar lemak pada Tabel 2 menjelaskan bahwa 
sampel darah memiliki kandungan lemak $0,02 \pm 0,00$, sedangkan sampel supernatan mempunyai kandungan protein lemak $0,01 \pm 0,00$, dan sampel pellet mempunyai kandungan lemak sebesar $0,01 \pm 0,01$. Kandungan lemak yang paling banyak terdapat pada darah mimi. Hal ini disebabkan sentrifuse tidak dapat memisahkan lemak dari peletnya dengan supernatan sehingga ada sebagian lemak terdapat dipelet dan sebagian disupernanatan.

Tabel 2. Kadar Lemak pada sampel

\begin{tabular}{llr}
\hline No & Keterangan & Rata-rata \\
\hline 1. & Sampel Darah & $0,02 \pm 0,00^{\mathrm{a}}$ \\
2. & Sampel Supernatan & $0,01 \pm 0,00^{\mathrm{b}}$ \\
3. & Sampel Pellet & $0,01 \pm 0,01^{\mathrm{c}}$ \\
\hline
\end{tabular}

Keterangan :

- Nilai pada tabel merupakan hasil rata-rata dari tiga ulangan

- Data yang diikuti tanda huruf kecil yang berbeda pada bagian atasnya menunjukkan adanya perbedaan nyata $(\mathrm{P}<0,05)$

\section{Kadar Fenol}

Berdasarkan uji statistik diperoleh hasil adanya perbedaan nyata $(\mathrm{P}<0,05)$. Hasil analisa kadar fenol pada Tabel 3 menjelaskan bahwa sampel darah memiliki kandungan fenol $0,23 \pm 0,02$, sedangkan sampel supernatan mempunyai kandungan protein fenol $0,33 \pm 0,00$, dan sampel pelet mempunyai kandungan lemak sebesar $0,17 \pm 0,00$. Kandungan fenol terbesar terdapat pada supernatan. Pengaruh dari sentrifuse megakibatkan fenol dapat keluar dari sel darah dan larut dalam supernatan.

Tabel 3. Kadar Fenol pada Sampel

\begin{tabular}{llr}
\hline No & Keterangan & Rata-rata \\
\hline 1. & Sampel Darah & $0,23 \pm 0,02^{\mathrm{a}}$ \\
2. & Sampel Supernatan & $0,33 \pm 0,00^{\mathrm{b}}$ \\
3. & Sampel Pelet & $0,17 \pm 0,00^{\mathrm{c}}$ \\
\hline
\end{tabular}

Keterangan :

- Nilai pada tabel merupakan hasil rata-rata dari tiga ulangan

- Data yang diikuti tanda huruf kecil yang berbeda pada bagian atasnya menunjukkan adanya perbedaan nyata $(\mathrm{P}<0,05)$

\section{Kadar Flavonoid}

Berdasarkan uji statistik diperoleh hasil adanya perbedaan nyata $(\mathrm{P}<0,05)$. Hasil analisa kadar flavonoid pada Tabel 4 menjelaskan bahwa sampel darah memiliki kandungan flavonoid $0,01 \pm 0,00$, sedangkan sampel supernatan mempunyai kandungan protein flavonoid $0,02 \pm 0,01$, dan sampel pelet mempunyai kandungan flavonoid sebesar $0.01 \pm 0.01$.

Flavonoid merupakan metabolit sekunder yang paling beragam dan tersebar luas. Flavonoid turunan dari senyawa fenol alam yang terdapat dalam hampir semua tumbuhan yang memiliki struktur dasar fenilbenzopiron (tokofenol) dicirikan oleh kerangka 15 karbon (C6-C3-C6) yang terdiri dari satu cincin teroksigenasi dan dua cincin aromatis, oleh karena itu kadar flavonoid pada ekstrak lebih kecil dibandingkan dengan kadar fenol. Menurut pendapat dari Dewi et al. (2014), bahwa senyawa flavonoid memiliki potensi sebagai antioksidan karena memiliki gugus hidroksil yang terikat pada karbon cincin aromatik sehigga dapat menangkap radikal bebas yang dihasilkan dari reaksi peroksidasi lemak. Senyawa flavonoid akan menyumbangkan satu atom hidrogen untuk menstabilkan radikal peroksi lemak.

Tabel 4. Kadar Flavonoid pada sampel

\begin{tabular}{lll}
\hline No & Keterangan & Rata-rata \\
\hline 1. & Sampel Darah & $0,01 \pm 0,00^{\mathrm{a}}$ \\
2. & Sampel Supernatan & $0,02 \pm 0,01^{\mathrm{b}}$ \\
3. & Sampel Pellet & $0.01 \pm 0.01^{\mathrm{c}}$ \\
\hline
\end{tabular}

Keterangan :

- Nilai pada tabel merupakan hasil rata-rata dari tiga ulangan

- Data yang diikuti tanda huruf kecil yang berbeda pada bagian atasnya menunjukkan adanya perbedaan nyata $(\mathrm{P}<0,05)$

\section{Kadar Lisin}

Berdasarkan uji statistik diperoleh hasil adanya perbedaan nyata $(\mathrm{P}<0,05)$. Hasil analisa kadar lysin pada Tabel 5 menjelaskan bahwa

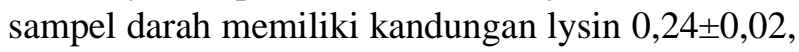
sedangkan sampel supernatan mempunyai kandungan protein lysin $0,25 \pm 0,01$, dan sampel pellet mempunyai kandungan lysin sebesar $0,27 \pm 0,01$. Kandungan lysine banyak terdapat pada pelet dibandingkan pada darah dan supernatant. Hal ini disebabkan pengaruh kecepatan sentrifuse tidak dapat mengeluarkan lysine yang masih terikat dengan sel darah. 


\section{Kadar Alkaloid}

Berdasarkan uji statistik diperoleh hasil adanya perbedaan nyata $(\mathrm{P}<0,05)$. Hasil analisa kadar alkaloid pada Tabel 6 menjelaskan bahwa sampel darah memiliki kandungan alkaloid $0,02 \pm 0,00$, sedangkan sampel supernatan mempunyai kandungan alkaloid $0,04 \pm 0,01$, dan sampel pelet mempunyai kandungan alkaloid sebesar 0,02 $\pm 0,01$. Kandungan alkaloid terbesar pada sampel supernatan. Hal ini disebabkan alkaloid dapat larut dengan supernatant karena pengaruh dari sentrifuse.

Tabel 5. Kadar Lysin pada sampel

\begin{tabular}{lll}
\hline No & Keterangan & Rata-rata \\
\hline 1. & Sampel Darah & $0,24 \pm 0,02^{\mathrm{a}}$ \\
2. & Sampel Supernatan & $0,25 \pm 0,01^{\mathrm{b}}$ \\
3. & Sampel Pellet & $0,27 \pm 0,01^{\mathrm{c}}$ \\
\hline
\end{tabular}

Keterangan :

- Nilai pada tabel merupakan hasil rata-rata dari tiga ulangan

- Data yang diikuti tanda huruf kecil yang berbeda pada bagian atasnya menunjukkan adanya perbedaan nyata $(\mathrm{P}<0,05)$

Tabel 6. Kadar Alkaloid pada sampel

\begin{tabular}{lll}
\hline No & Keterangan & Rata-rata \\
\hline 1. & Sampel Darah & $0,02 \pm 0,00^{\mathrm{a}}$ \\
2. & Sampel Supernatan & $0,04 \pm 0,01^{\mathrm{b}}$ \\
3. & Sampel Pellet & $0,02 \pm 0,01^{\mathrm{c}}$ \\
\hline
\end{tabular}

Keterangan :

- Nilai pada tabel merupakan hasil rata-rata dari tiga ulangan

- Data yang diikuti tanda huruf kecil yang berbeda pada bagian atasnya menunjukkan adanya perbedaan nyata $(\mathrm{P}<0,05)$

\section{Kadar Saponin}

Berdasarkan uji statistik diperoleh hasil adanya perbedaan nyata $(\mathrm{P}<0,05)$. Hasil analisa kadar saponin pada Tabel 7 menjelaskan bahwa sampel darah memiliki kandungan saponin $0,06 \pm 0,01$, sedangkan sampel supernatan mempunyai kandungan saponin $0,08 \pm 0,01$, dan sampel pelet mempunyai kandungan saponin sebesar 0,02 $\pm 0,01$. Kandungan saponin paling banyak terdapat pada supernatan jika dibandingkan dengan darah dan pelet. Hal ini disebabkan pengaruh sentrifuse yang menyebabkan saponin terkandung pada darah mimi akan terbawa supernatan.

Tabel 7. Kadar Saponin pada sampel

\begin{tabular}{llr}
\hline No & Keterangan & Rata-rata \\
\hline 1. & Sampel Darah & $0,06 \pm 0,01^{\mathrm{a}}$ \\
2. & Sampel Supernatan & $0,08 \pm 0,01^{\mathrm{b}}$ \\
3. & Sampel Pellet & $0,02 \pm 0,01^{\mathrm{c}}$ \\
\hline
\end{tabular}

Keterangan :

- Nilai pada tabel merupakan hasil rata-rata dari tiga ulangan

- Data yang diikuti tanda huruf kecil yang berbeda pada bagian atasnya menunjukkan adanya perbedaan nyata $(\mathrm{P}<0,05)$

\section{Skrining dengan bakteri patogen}

Hasil sampel darah dan supernatan, serta pelet setelah diisolasi dan skrining dengan bakteri patogen. Berdasarkan tabel 8. menjelaskan bahwa baik sampel darah supernatant dan pellet tidak menghasilkan zona hambat terhadap bakteri patogen. Konsentrasi pengenceran terlalu kecil.

\section{KESIMPULAN}

Hasil isolasi darah dari 10 ekor mimi yaitu $165,72 \mathrm{ml}$. Setelah disentrifuse dihasilkan supernatant 90,633 $\mathrm{ml}$ dan 23,304 pelet. Hasil analisis fitokimia banyak dihasilkan pada supernatan terutama alkaloid, fenol, tannin, alkaloid. Berdasarkan skrining dengan bakteri patogen tidak dihasilkan zona hambat karena pengenceran terlalu kecil.

Tabel 8.Skrining sampel dengan bakteri patogen

\begin{tabular}{lllllllllll}
\hline \multirow{2}{*}{ No } & \multirow{2}{*}{ Keterangan } & \multicolumn{3}{c}{ Eschericia coli } & \multicolumn{3}{c}{ Staphylococcus aureus } & \multicolumn{3}{c}{ Salmonella } \\
\cline { 3 - 10 } & & $5 \%$ & $10 \%$ & $15 \%$ & $5 \%$ & $10 \%$ & $15 \%$ & $5 \%$ & $10 \%$ & $15 \%$ \\
\hline 1. & Sampel Darah & - & - & - & - & - & - & - & - & - \\
2. & Sampel Supernatan & - & - & - & - & - & - & - & - & - \\
3. & Sampel Pelet & - & - & - & - & - & - & - & - & - \\
\hline
\end{tabular}



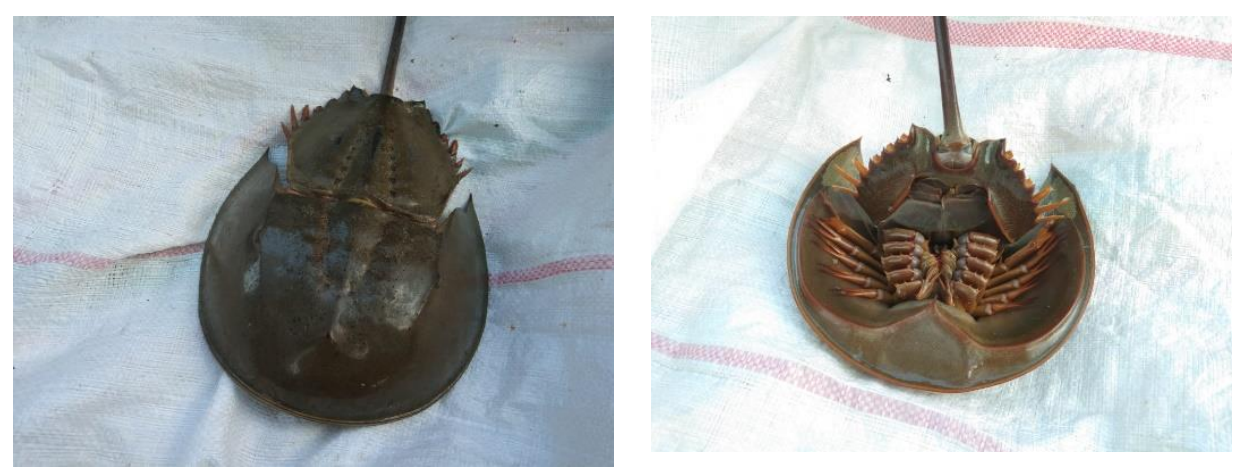

Gambar 1. Mimi (Tachypleus gigas)
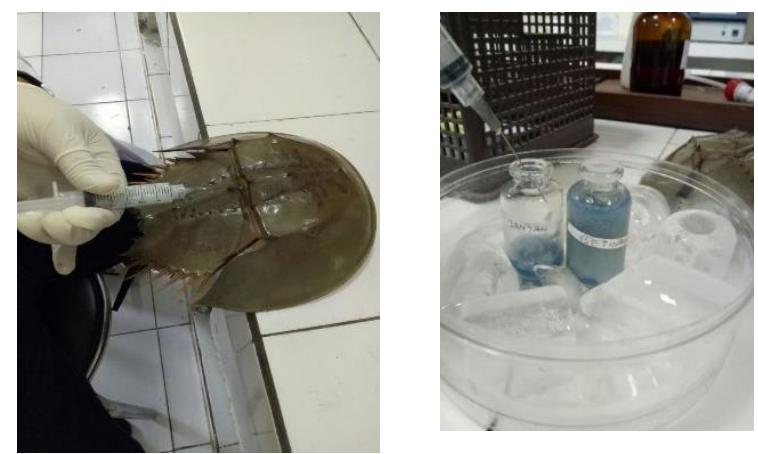

Gambar 2. Proses Pengambilan darah mimi

\section{DAFTAR PUSTAKA}

[AOAC] Association of Official Analytical Chemist. 2005. Official Methods of Analysis of The Association of Official Analytical Chemist. Arlington, Virginia (USA): Association of Official Analytical Chemists Inc.

Dewi, N.W.O.A., Puspawati, N.M., Swantara, I. M.D., Asih, I.A.R.A., \& Rita, W.S. 2014. Aktivitas Antioksidan Senyawa Flavonoid Ekstrak Etanol Biji Terong Belanda (Solanum betaceum, syn) dalam Menghambat Reaksi Peroksidasi Lemak pada Plasma Darah Tikus Wistar. Cakra Kimia, 2(1):9-9.

Funkhouser, D. 2011. Crab love nest. Scientific American, 304(4):29-29. DOI :10.1038/ scientific American0411-29

Hardiana, R., \& Rudiyansyah, T. A. 2013. Aktivitas antioksidan senyawa golongan fenol dari beberapa jenis tumbuhan Famili Malvaceae. Jurnal Kimia Khatulistiwa, 1(1):8-13

Leschen, A.S., \& Correia, S.J. 2010. Mortality in female horseshoe crabs (Limulus polyphemus) from biomedical bleeding and handling: implications for fisheries management. Marine and Freshwater Behaviour and Physiology, 43(2):135-147.

Lembaga Oseanologi Nasional-Lembaga Ilmu Pengetahuan Indonesia 1973. Bahan Makanan Dari Laut. Pusat Dokumentasi Ilmiah Nasional h. 78-79.

Monica,M., Ediyanto, H.\& Jahidin, J.P. 2016. Pengembangan Usaha Pembesaran Belangkas di Kampung Laut Tanjung Jabung Timur. Jurnal Pengabdian pada Masyarakat. 31(2):48-56

Meilana.L, Wardiatno. Y, Butet. N.A, Krisanti. M. 2016. Karakterisasi morfologi dan identifikasi molekuler dengan marka gen Co1 pada mimi (Tachypleus gigas) di Utara Pulau Jawa. Jurnal Ilmu dan Teknologi Kelautan Tropis, 8(1):145-158.

Rohaeti, E., Heryant, R., Rafi, M., Wahyuningrum, A., \& Darusman, L.K. 2011. Prediksi kadar flavonoid total tempuyung (Sonchus arvensis L.) menggunakan kombinasi spektroskopi IR dengan regresi kuadrat terkecil parsial. Jurnal kimia, 5(2): 101-108.

Rubiyanto, E. 2012. Studi populasi mimi (Xiphosura) di Perairan Kuala Tungkal, Kabupaten Tanjung Jabung Barat, Jambi [Doctoral dissertation]. Universitas Indonesia. $66 \mathrm{hlm}$. 